\title{
Goblet cell carcinoid of the appendix
}

\author{
K Park, K Blessing, K Kerr, U Chetty, H Gilmour
}

\begin{abstract}
We have reviewed all cases of goblet cell carcinoid in the Department of Pathology, Edinburgh University. Of the 10 cases identified, two had died as a result of the tumour. This would suggest a poorer prognosis than is generally recognised. Those patients who subsequently had progression of their disease were not predicted by histological criteria. Because of the unpredictable behaviour of these tumours we recommend that such patients should correctly be treated by a right hemicolectomy.
\end{abstract}

The goblet cell carcinoid of the vermiform appendix as a separate entity from adenocarcinoma and carcinoid tumours was first recognised in 1974.' It has, however, been described under a number of different names such as mucinous or mucin producing carcinoid ${ }^{23}$ adenocarcinoid, ${ }^{34}$ intermediate type of carcinoid, ${ }^{5}$ and crypt cell carcinoma. ${ }^{6}$ Although

TABLE I Clinical presentation of patients with goblet cell carcinoid of the appendix

\begin{tabular}{|c|c|c|c|c|c|}
\hline Patient & Age & Sex & Presentation & Operation & Outcome \\
\hline 1 & $\mathbf{M}$ & 56 & $\begin{array}{l}\text { Vague abdominal } \\
\text { pain }\end{array}$ & $\begin{array}{l}\text { Appendicectomy } \\
\text { (R) hemicolectomy } \\
\text { 4 weeks later }\end{array}$ & $\begin{array}{l}\text { Death due to metastatic disease } \\
3 \text { years }\end{array}$ \\
\hline 2 & F & 80 & Acute appendicitis & Appendicectomy & $\begin{array}{l}\text { Alive free from recurrent disease } \\
15 \text { years }\end{array}$ \\
\hline 3 & $\mathbf{M}$ & 62 & Acute appendicitis & Appendicectomy & $\begin{array}{l}\text { Alive free from recurrent disease } \\
2 \text { years }\end{array}$ \\
\hline 4 & $\mathrm{~F}$ & 44 & Appendix mass & Appendicectomy & $\begin{array}{l}\text { Death due to metastatic disease } \\
3 \text { years }\end{array}$ \\
\hline 5 & $M$ & 24 & Acute appendicitis & Appendicectomy & $\begin{array}{l}\text { Alive free from recurrent disease } \\
3 \text { years }\end{array}$ \\
\hline 6 & $M$ & 38 & Appendix mass & Appendicectomy & $\begin{array}{l}\text { Alive free from recurrent tumour } \\
2 \text { years }\end{array}$ \\
\hline 7 & $\mathbf{M}$ & 48 & Acute appendicitis & $\begin{array}{l}\text { Appendicectomy } \\
\text { (R) hemicolectomy } \\
15 \text { years later }\end{array}$ & $\begin{array}{l}\text { Alive, recurrent disease } 15 \text { years } \\
\text { later presented as small bowel } \\
\text { obstruction }\end{array}$ \\
\hline 8 & $\mathbf{M}$ & 71 & Acute appendicitis & Appendicectomy & $\begin{array}{l}\text { Alive, free from recurrent tumour } \\
6 \text { years }\end{array}$ \\
\hline 9 & M & 72 & Acute appendicitis & $\begin{array}{l}\text { Appendicectomy } \\
\text { (R) hemicolectomy } \\
6 \text { weeks later }\end{array}$ & Alive, no recurrent tumour \\
\hline 10 & $\mathbf{M}$ & 65 & Appendix mass & $\begin{array}{l}\text { Appendicectomy } \\
\text { (R) hemicolectomy } \\
5 \text { weeks later }\end{array}$ & $\begin{array}{l}\text { Alive residual tumour found in } \\
\text { caecum and appendiceal stump }\end{array}$ \\
\hline
\end{tabular}

The Department of Clinical Surgery, The Royal Infirmary of Edinburgh, Edinburgh K Park U Chetty

The Department of Pathology, The University of Edinburgh, Edinburgh K Blessing K Kerr

H Gilmour

Correspondence to: $\mathrm{Mr} \mathrm{K}$ Park, FRCS, Department of Surgery, Aberdeen University, Foresterhill, Aberdeen.

Accepted for publication 6 June 1989 there has been much interest in this tumour, in particular with regard to its histogenesis, the relative rarity of the tumour ${ }^{2}$ has meant that firm conclusions on its behaviour and prognosis are difficult to draw, and much of the literature on this subject is contradictory. ${ }^{1278}$ It was decided, therefore, to investigate the incidence and behaviour of this tumour as recorded in the files of the University of Edinburgh Pathology Department.

\section{Methods}

PATIENTS

The number of malignant appendiceal neoplasms during the past 25 years was determined from the records of the Pathology Department in the University of Edinburgh and in each case the pathology was reviewed. The pathological review being retrospective was confined to the macroscopic description of the specimens in the reports issued to the clinicians and histological examination of the slides and blocks in the files. The histological criteria for diagnosis of the goblet cell carcinoid tumour were those of previous authors. ${ }^{1379}$ In each case information regarding the position and extent of the tumour, the mitotic activity, degree of differentiation, and lymphatic involvement was recorded.

Clinical information was obtained from the case notes including patient follow up, when available. If follow up information was not available, the patients' general practitioners were contacted and in this way follow up has been complete with a range of time from six months to 15 years.

\section{Results}

After histological review of all the cases reported as malignant tumours (adenocarcinoma and goblet cell carcinoid) of the appendix, 10 cases fulfilled the criteria for a diagnosis of goblet cell carcinoid. No new cases were identified during the review, although one case (patient 4) only came to light after a recurrence, the original diagnosis being missed. Eight of the patients were men aged from 24-80 years. Six patients presented as acute appendicitis, three with an appendix mass and one with vague abdominal pain (Table I).

The initial treatment in each case was a routine appendicectomy. After diagnosis of a goblet cell carcinoid tumour three patients underwent a subsequent limited right hemicolectomy within eight weeks of the initial operation, and a fourth required a right hemicolectomy 15 years later for recurrent disease.

The tumour was present in the distal segment of the appendix in seven of the cases, the proximal segment in two and the mid-segment in one. In only one case was the histological pattern slightly atypical, all the others showing the classical microscopic appearance (Fig 1). The tumour was invasive in all cases extending into the muscularis propria (Fig 2) and in six cases invasion had occurred through the muscle into the subserosal tissue. Mitotic activity was not prominent in any case (Table II).

There are eight patients for whom follow up information is available at two years and all survived this period. Five patients have been followed up for five years, during which time there were two deaths from metastatic disease, both three years after the original operation. The acturial two and five year survival is therefore $100 \%$ and $60 \%$ respectively. Only two patients have been followed up for longer than 10 years, 


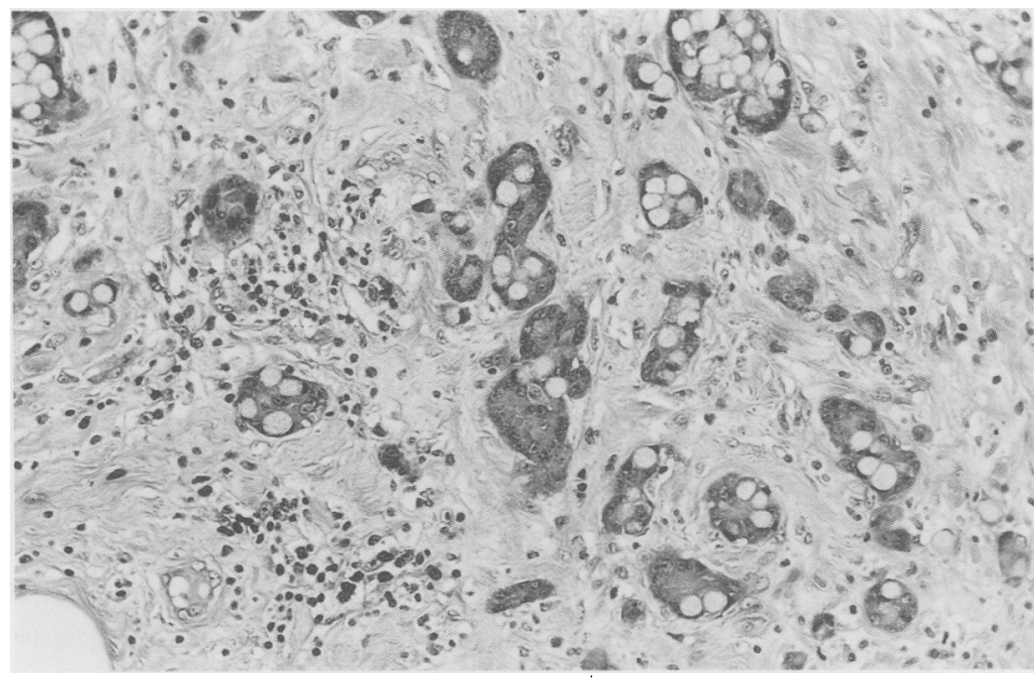

Figure 1: Typical small cellular aggregates of the tumour composed of mucin secreting and enterochromaffin cells $(H \mathcal{G} E)$.

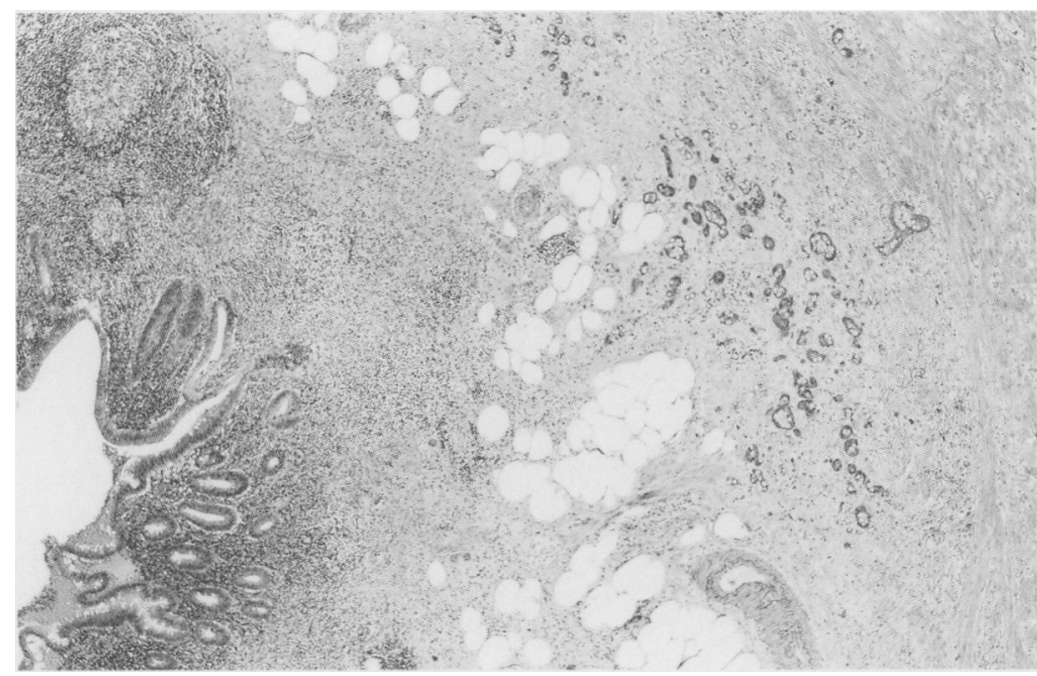

Figure 2: The tumour is present in the submucosa and invades the muscularis propria. Acute inflammation is also noted within the mucosa $(H \mathcal{E} E)$.

TABLE II Pathological details of patients

\begin{tabular}{|c|c|c|c|c|c|c|}
\hline Patient & $\begin{array}{l}\text { Position of } \\
\text { tumour }\end{array}$ & $\begin{array}{l}\text { Extent of } \\
\text { tumour }\end{array}$ & $\begin{array}{l}\text { Mitotic } \\
\text { activity }\end{array}$ & $\begin{array}{l}\text { Lymphatic } \\
\text { involvement }\end{array}$ & Differentiation & Clinical outcome \\
\hline 1 & Proximal & $\begin{array}{l}\text { Subserosal } \\
\text { tissue } \\
\text { involved }\end{array}$ & Low & Yes & Good & $\begin{array}{l}\text { Death } 3 \text { years after } \\
\text { diagnosis }\end{array}$ \\
\hline 2 & Distal & $\begin{array}{l}\text { Subserosal } \\
\text { tissues } \\
\text { involved }\end{array}$ & Low & Yes & Good & $\begin{array}{l}\text { Alive, free from } \\
\text { recurrence } \\
15 \text { years }\end{array}$ \\
\hline 3 & Distal & $\begin{array}{l}\text { Superficial } \\
\text { muscle } \\
\text { invaded }\end{array}$ & Low & Yes & Good & $\begin{array}{l}\text { Alive, free from } \\
\text { recurrence } \\
2 \text { years }\end{array}$ \\
\hline 4 & Distal & $\begin{array}{l}\text { Subserosal } \\
\text { tissues } \\
\text { involved }\end{array}$ & None & Yes & Good & $\begin{array}{l}\text { Death, } 3 \text { years after } \\
\text { diagnosis }\end{array}$ \\
\hline 5 & Distal & $\begin{array}{l}\text { Muscle } \\
\text { invaded }\end{array}$ & Low & No & Atypical & $\begin{array}{l}\text { Alive, free from } \\
\text { recurrence } \\
3 \text { years }\end{array}$ \\
\hline 6 & $\begin{array}{l}\text { Mid portion } \\
\text { (one-third) }\end{array}$ & $\begin{array}{l}\text { Subserosal } \\
\text { tissues } \\
\text { involved }\end{array}$ & Low & Yes & Good & $\begin{array}{l}\text { Alive, free from } \\
\text { recurrence } \\
2 \text { years }\end{array}$ \\
\hline 7 & Distal & $\begin{array}{l}\text { Muscle } \\
\text { invaded }\end{array}$ & Low & Yes & Good & $\begin{array}{l}\text { Alive recurrence after } 15 \\
\text { years }\end{array}$ \\
\hline 8 & Distal & $\begin{array}{l}\text { Subserosal } \\
\text { tissues } \\
\text { involved }\end{array}$ & Low & No & Good & $\begin{array}{l}\text { Alive, no recurrence after } \\
6 \text { years }\end{array}$ \\
\hline 9 & Distal & $\begin{array}{l}\text { Muscle } \\
\text { invaded }\end{array}$ & Low & No & Good & $\begin{array}{l}\text { Alive, no recurrence after } \\
6 \text { months }\end{array}$ \\
\hline 10 & Proximal & $\begin{array}{l}\text { Subserosal } \\
\text { tissues } \\
\text { involved }\end{array}$ & Low & No & Good & $\begin{array}{l}\text { Alive, residual tumour in } \\
\text { caecum at right hemi- } \\
\text { colectomy } \\
2 \text { months }\end{array}$ \\
\hline
\end{tabular}

${ }^{\star}$ Mitotic activity: low $<2 \times 10 \mathrm{hpf}$ both are alive 15 years after their initial surgery, although one of these patients has recently presented with a recurrence of his tumour. One other patient was found to have residual tumour in the right hemicolectomy specimen resected two months after an initial appendicectomy. There were therefore four patients with evidence of recurrent or residual tumours after initial treatment by appendicectomy, in each case the pattern of spread has been local and to draining lymph nodes, confirmed by laparotomy and in the two cases who died, at necropsy. Comparison of the outcome with the histological features shows that these four patients with recurrent disease did not have any distinguishing microscopic appearances which would have indicated a poor prognosis (Table II).

\section{Discussion}

The diagnosis of goblet cell carcinoid of the appendix is essentially made on histological grounds. In the reported series there were no features in the clinical history or the macroscopic appearance which suggested the diagnosis to the surgeon or pathologist. The diagnosis is only made therefore, after careful histological examination of an appendicectomy specimen, and a decision then has to be made as to whether further treatment is necessary.

Previous authors have noted the more aggressive behaviour of goblet cell carcinoid tumours compared with simple appendiceal carcinoids. ${ }^{13710}$ The five year actuarial survival rate for the series reported from the Armed Forces Institute of Pathology was $80 \%^{3}$ and in a review of the literature Edmonds found that of 86 recorded cases of goblet cell carcinoid tumours, 11 had died and a further three had recurrent disease. ${ }^{7}$ In this study the actuarial five year survival was $60 \%$, in addition another one patient had residual tumour in this subsequent hemicolectomy specimen and a further patient developed local recurrence.

It is generally accepted that adenocarcinoma of the appendix behaves in a similar manner to caecal carcinoma and therefore warrants a radical surgical approach. ${ }^{112}$ The optimal treatment of goblet cell carcinoid tumours, however, is unclear; attempts have been made in the past to predict the behaviour of individual tumours on the basis of histological appearances, so that treatment could be modified accordingly. ${ }^{13}$ In this study, we looked at five histological parameters used by others to predict behaviour. ${ }^{1310}$ In a small study such as this, the numbers involved are not of statistical significance, but none of these factors were of value in predicting the patients who eventually died of their tumour or who had evidence of recurrent disease. Because of this unpredictable behaviour and the pattern of recurrence seen, an elective right hemicolectomy after the diagnosis has been established would appear to provide the best chance of controlling the disease. Before this could be recommended in all patients, however, the potential benefits must be balanced against the possible morbidity and mortality associated with this procedure. In the Lothian Area the mortality of elective right hemicolectomy, for all 
diseases between 1986 and 1987 was $4 \%$. This figure, however, includes many high risk groups including patients undergoing an extended right hemicolectomy, the mortality for a standard operation performed under optimal conditions, in an otherwise healthy patient is unlikely to greatly exceed that associated with the anaesthetic. Although morbidity such as diarrhoea may occur in up to $50 \%$ of patients undergoing (R) hemicolectomy ${ }^{13}$ this usually resolves with time. ${ }^{1+}$ We propose, therefore, that a right hemicolectomy is the definitive surgical treatment in all patients otherwise fit enough for a further laparotomy.

The authors would like to thank the Surgeons in The Lothian and Borders Region, who allowed us to study their patients, and in addition, Mr C Windsor, Worcester Royal Infirmary and Mr S Nixon from the Lothian Audit Group.

1 Subbuswamy SG, Gibbs NM, Ross CF, Morson BC. Goble cell carcinoid of the appendix. Cancer 1974; 34: 338-44.

2 Klein HZ. Mucinous carcnoid tumour of the vermiform appendix. Cancer 1974; 33: 770-7.
3 Warkel RL, Cooper PH, Helwig EB. Adenocarcinoid, a mucin producing tumour of the appendix. A Study of 39 Cases. producing tumour of the

4 Olsson B, Ljungberg O. Adenocarcinoid of the Vermiform Appendix. Virchows Arch [Pathol Anat] 1980; 386: 201-10.

5 Gagne F, Fortin P, Dufour V, Dulage C. Tumeurs de l'appendice associant des caracteres histologiques de carcinoide et de'adenocarcinome. Ann Anat Pathol 1969; 14: 393-406.

6 Isaacson P. Crypt cell carcinoma of the appendix (so-called adenocarcinoid tumour). Am F Surg Pathol 1981; 5: 213-24.

7 Edmonds P, Merino MJ, Livolsi VA, Duray PH. Adenocarcinoids (mucinous carcinoid) of the appendix. Gastroenterology 1984; 86: 302-9.

8 Berardi RS, Lee SS, Chen HP. Goblet cell carcinoids of the Appendix. Surg Gynecol Obstet 1988; 767: 81-6.

9 Abt AB, Carter SL. Goblet cell carcinoid of the appendix. An ultrastructural and histochemical study. Arch Pathol Lab
a Med 1976; 100: 301-6.

10 Hernandez FJ, Reid JD. Mixed carcinoid and mucous secreting intestinal tumours. Arch Pathol 1969; 88: 489-96.

11 Collins DC. 71,000 human appendix specimens: a final report. Am $\mathcal{F}$ Proct 1983; 14: 265-9.

12 Sieracki JC, Tesluk $\mathrm{H}$. Primary adenocarcinoma of the vermiform appendix. Cancer 1956; 9: 997.

13 Gazet JC. The surgical significance of the ileo-caecal junction. Ann R Coll Surg Engl 1968; 43: 19-37.

14 Jewkes AJ, Windsor CWO, Ward RS, Timmins AE. Relationship between bile and malabsorption using the "Se homocholic acid taurine scanning method and diarrhoea following right hemicolectomy. Br F Surg 1989; 76: 707-8. 